Volume 114

Issue 2 Dickinson Law Review - Volume 114,

2009-2010

10-1-2009

\title{
Imagining Judges that Apply Law: How They Might Do It
}

James R. Maxeiner

Follow this and additional works at: https://ideas.dickinsonlaw.psu.edu/dlra

\section{Recommended Citation}

James R. Maxeiner, Imagining Judges that Apply Law: How They Might Do It, 114 DICK. L. Rev. 469 (2009). Available at: https://ideas.dickinsonlaw.psu.edu/dlra/vol114/iss2/4

This Article is brought to you for free and open access by the Law Reviews at Dickinson Law IDEAS. It has been accepted for inclusion in Dickinson Law Review by an authorized editor of Dickinson Law IDEAS. For more information, please contact lja10@psu.edu. 


\title{
Imagining Judges that Apply Law: How They Might Do It
}

\author{
James R. Maxeiner*
}

Table of Contents

THE RELATIONSTECHNIK OF APPLYING LAW TO FACTS ....................472

THE GERMAN JUDGMENT AS "NARRATIVE" ................................... 475

THE RELATIONSTECHNIK AS GUIDE TO APPLYING LAW TO FACTS...... 476

(1) Reviewing the Complaint for Plausibility before Serving... 477

(2) Case Structuring through Issue Framing ...................... 478

(3) Focusing Witness Testimony...................................... 480

(4) Deferring Final Decision of Issues.............................. 481

AMERICAN REFLECTIONS ON THE GERMAN RELATIONSTECHNIK........481

\begin{abstract}
"Judges should apply the law, not make it." That plea appears perennially in American politics. American legal scholars belittle it as a simple-minded demand that is silly and misleading. A glance beyond our shores dispels the notion that the American public is naïve to expect judges to apply rather than to make law.
\end{abstract}

* Associate Professor of Law, University of Baltimore School of Law. J.D. Cornell, LL.M. Georgetown, Ph. D. in Law (Dr. jur.) Ludwig Maximilian University Munich. This essay is based on a presentation and submission to Panel 4: Imagining New Structures of Civil Justice (Including a Comparative Review) of the Common Good Forum "The Boundaries of Litigation, A Forum Addressing the Alignment of Civil Justice with Social Goals," held at the Brookings Institution, Washington DC, April 15, 2008 , and commissioned by the Common Good organization. The author would like to thank the Common Good organization and Philip K. Howard for their support, as well as the other members of the panel, Justice Anthony M. Kennedy, Lord Leonard Hoffmann, Professor Gillian K. Hadfield, Mr. Robert E. Litan, Professor Peter H. Schuck, Professor Anthony J. Sebok, Professor Lars Trägårdh and Judge John M. Walker. The views expressed are those of the author. 
American obsession with judicial lawmaking has its price: indifference to judicial law applying. If truth be told, practically we have no method for judges, as a matter of routine, to apply law to facts. Our failure leads American legal scholars to question whether applying law to facts is a necessary feature of civil procedure at all.

German civil justice does have a method for routinely applying law to facts. It is called, in German, the "Relationstechnik," that is, in English, literally "relationship technique." This article introduces it to American lawyers and judges and shows how it helps make German civil justice effective.

"Judges should apply the law, not make it." That plea appears perennially in American politics. ' American legal scholars belittle it as a "simple-minded demand" that is "silly and misleading." It is, they suggest, a product of lay naïveté. "[E]very lawyer knows that judges make law-it's their job." That the plea finds resonance, however, is symptomatic of a popular perception of misalignment of civil justice with social goals. If law is not applied, but is left to judges to be made, it cannot be the expression of the people's social goals that it should be. ${ }^{5}$

A glance beyond our shores dispels the notion that the American public is naïve to expect judges to apply rather than to make law. An Englishman, H.L.A. Hart, reminded U.S. jurists that "conventional legal

1. Compare 2 THE Works OF JAMES WILSON 502 (Robert Green McCloskey ed., 1967) (1804) ("[E]very prudent and cautious judge ... will remember, that his duty and his business is, not to make the law, but to interpret and apply it.") with Press Release, George W. Bush, President Announces Judge John Roberts as Supreme Court Nominee, (July 19, 2005), available at http://georgewbush-whitehouse.archives.gov/news/ releases/2005/07/20050719-7.html ("He will strictly apply the Constitution and laws, not legislate from the bench.").

2. John J. Flynn, "Making Law" and "Finding Facts" - Unavoidable Duties of an Independent Judiciary, UTAH B.J., Aug. 6, 2005, at 6, 7, available at http://www.utahbar.org/barjournal/pdf/2005_july_august.pdf.

3. Erwin Chemerinsky \& Catherine Fisk, Judges Do Make Law-It's Their Job, USA TODAY, August 24, 2005, at 11 A.

4. Id.

5. See, e.g., Justice Stephen J. Breyer, A Conversation on the Relevance of Foreign Law for American Constitutional Adjudication with U.S. Supreme Court Justices Antonin Scalia \& Stephen Breyer (Jan. 13, 2005) (transcript available at http://domino.american.edu/AU/media/mediarel.nsf/1D265343BDC2189785256B81007 IF238/1F2F7DC4757FD01E85256F890068E6E0?OpenDocument) ("The judge is to apply the law... [R]emember, a judge is a person who's been entrusted in a democratic society with power, although that judge is not elected. So if in fact you give judges too many open-ended procedures, rules and practices, what you will discover is that a man, a woman who suddenly has this power, for better or for worse, maybe unconsciously, maybe not even wanting to, will substitute her judgment, his judgment, for the judgment of the legislature. And that's wrong in a democracy."). 
thought in all countries conceives as the standard judicial function the impartial application of determinant existing rules in the settlement of disputes." 6 Nowhere, except perhaps here in the United States, has the recognition that some judges, sometimes, make law, shaken the conventional idea that the standard function of civil litigation is applying law to facts. And even here, that shaken faith is a relatively recent development.

American obsession with judicial lawmaking has its price: indifference to judicial law applying. We use our methods of applying law to facts-e.g., jury trials, summary judgments, and complaint screening-haphazardly rather than routinely. We rely on the parties' lawyers to determine the subject for decision rather than on judges. We depend upon those parties, rather than on courts, to invoke mechanisms for deciding. As a result, trials are vanishing, summary judgment motions are sporadic, and complaints are rarely reviewed by courts before service. It is said of American civil justice that the "highest goal is for courts not to apply law to facts."7

If truth be told, practically we have no method for judges, as a matter of routine, to apply law to facts. Our abject failure leads American legal scholars to question whether applying law to facts is a necessary feature of civil procedure at all. In their view, process and participation in the process are primary; decisions that determine rights according to law are secondary, at best, and impossible to achieve, at worst.

The Common Good Forum on the "Boundaries of Litigation" held last year at The Brookings Institution challenged us to "Imagin[e] New Structures of Civil Procedure." How can we do that? "Imagining" truly new structures of civil procedure is a daunting challenge beyond any one person's capabilities. One way that we can imagine new systems without stretching our imaginations beyond the breaking point is to observe other legal systems.

In this essay I discuss the German method of judicial application of law to facts. Our two societies and our two legal systems are sufficiently similar to make their experiences mutually relevant and informative. Above all, the two systems of civil justice are united by a common goal: "the fair, accurate and efficient vindication of private rights and interests based on the existing legal, political and social order."

6. H.L.A. Hart, American Jurisprudence Through English Eyes: The Nightmare and the Noble Dream, 11 GA. L. REV. 969, 971 (1977).

7. Stephen N. Subrin, How Equity Conquered Common Law: The Federal Rules of Civil Procedure in Historical Perspective, 135 U. PA. L. REV. 909, 989 (1987).

8. Peter L. Murray \& Rolf Stürner, German Civil Justice 575 (2004). 
German civil justice does have a method for routinely applying law to facts. It is called, in German, the "Relations-technik," that is, in English, literally "relationship technique." In this essay I introduce it to American lawyers and judges. After a brief presentation of the Relationstechnik, I show how it helps keep German civil justice-as Philip Howard might say_-"sane,"

\section{THE RELATIONSTECHNIK OF APPLYNG LAW TO FACTS}

The syllogism is the basis of the Relationstechnik: the legal rule is the major premise, the facts are the minor premise, and the judicial decision is the logical conclusion. The Relationstechnik is taught to all future German judges and lawyers in court-provided training that takes place after conclusion of their university studies. The Relationstechnik is a product of more than a century of judicial practice.

Two "bookends" of the Relationstechnik guide judges in applying law to facts: the legislatively-promulgated statute (das Gesetz) and the judicially written judgment (das Urteil).

The statute is the fundamental concept of all German law. German statutes take the form of syllogistic norms. The major premise is that a legal consequence prescribed by statute applies when a generally described state of facts is present. The minor premise is that a particular state of facts fulfills the statutorily prescribed state of facts.

The Relationstechnik works best when statutes in substance and form are good. Bad statutes make bad decisions. When statutes reflect prevailing conceptions of justice, the Relationstechnik is spared the tension of choosing between statutory rules and justice. ${ }^{11}$ When statutes are well drafted, the Relationstechnik functions smoothly; hard cases are few, and easy cases are many.

9. The Relationstechnik is little discussed in English. To my knowledge, until 2004, the only work was Walter O. Weyrauch, The Art of Drafting Judgments: A Modified German Case Method, 9 J. LEGAL EDUC. 311 (1957). For two recent works, see also Christoph Engel, The Impact of Representation Norms on the Quality of Judicial Decisions 16 (Max Planck Inst. for Research on Collective Goods, Working Paper No. 2004/13, 2004), available at http://www.mpp-rdg.mpg.de/pdf_dat/2004_13online.pdf; Lutz-Christian Wolff, Structured Problem Solving: German Methodology from a Comparative Perspective, 14 LEGAL EDUC. REv. 19 (2003-2004), available at http://www.ler.edu.au/pdf/volumes/ler_vol14_1_2003_04.pdf. The paucity of Englishlanguage treatments may be attributed to the fact that the method is principally taught at the courts in the practical training period of German legal education rather than in the university law faculty.

10. See Philip K. Howard, Making Civil Justice Sane, CITY Journal, Spring 2006, at 64 .

11. Article 20(3) of the German Constitution binds judicial decisions to "statute and justice" (Gesetz und Recht). GRUNDGESETZ [GG] [Constitution] art. 20(3) (F.R.G.). 
Well-drafted statutes coordinate well with each other. Well-drafted statutes make clear who may invoke them and what the consequences of their invocation are. Well-drafted statutes, to the extent possible, have judges find objective facts rather than make subjective valuings. Welldrafted statutes do not expect judges to make political or other social policy decisions. While well-drafted statutes often require judges to value individual equities and find subjective facts such as state of mind, they minimize the use of such decisions to the extent they can. When they cannot avoid such decisions, they guide those decisions by setting boundaries and by giving examples.

Statutes are not drafted well by accident. Most modern legal systems have a central office responsible for the technical quality of statutes. In Germany, preparation and perpetuation of good legislation is the raison d'être of the Federal Ministry of Justice. ${ }^{12}$ In that work, the Ministry engages some of the land's the best-qualified jurists: former appellate judges.

While statutes guide law application, judgments validate their correct application. Judgments have four parts: (1) a caption that identifies the parties and the lawsuit ("Rubrum"); (2) a statement of the decision and of the relief ordered ("Tenor"); (3) a Tatbestand; ${ }^{13}$ and (4) the grounds for decision ("Entscheidungsgründe"), hereafter referred to as the "justification." All four parts are subject to strict rules as to style. The first two parts need no explanation; the last two do.

The Tatbestand is a short statement of the parties' legal claims and of their assertions of fact. It is not a finding of facts and thus is not an analogue to the findings of fact of an American bench decision. The Tatbestand should include: the subject matter of the lawsuit, a detailed sketch of the facts, but only insofar as is necessary to establish clearly the subject of the lawsuit, the evidence offered by the parties, the applications of the parties, relevant history of the lawsuit, and specific references to the file. It should not include: facts not necessary to the

12. The Ministry's website identifies its central mission: "Law constitutes the foundation of our free democracy. Guaranteeing the rule of law and pursuing further refinements in this area is a central task of legal policy, and thus also of the Federal Ministry of Justice. The legislative work undertaken by the Ministry pursues this objective, and encompasses the preparation of new legislation as well as the amendment or repeal of existing laws." http://www.bmj.bund.de/enid/9f0ca456efff7ed197073e2dd $5 \mathrm{~d} 372 \mathrm{a} 5,0 /$ Ministry/Structure_and_Organisation_14p.html

13. Tatbestand is a legal term which has no single English translation. Depending upon the context in which it appears, a different English translation is appropriate. In this essay, Tatbestand refers to a specific part of a German judgment that is so designated. There is no formal counterpart to the Tatbestand in an American judgment. To avoid inducing a false understanding, it is left here in the original German. Readers should note that this meaning is different from the Tatbestand of German criminal law, which might be translated "elements of the offense." 
decision of the case, party statements made in the proceedings that are no longer relevant, legal arguments of the parties, statements of the law, or normative evaluations of the facts.

The justification applies law to facts. It determines the facts of the Tatbestand and subsumes them under the abstract elements of the applicable rules. The process of applying law to facts is not a mechanical act of mindless processing, but a mindful act of creative evaluation.

The justification follows a format that in clarity and brevity facilitates understanding. It begins by stating the result of the lawsuit and by identifying the determinative legal rule. It confirms or denies that the plaintiff's claim is permissible under procedural law and wellfounded in substantive law. For example, a typical justification might begin: "The plaintiff's action is in all respects permissible and wellfounded. Pursuant to $\S 488$ Paragraph 1 Sentence 2 of the Civil Code the plaintiff has a right arising from the loan agreement of December 12, 2007 , to repayment of the loan of $€ 75,000$."

The justification then proceeds to address systematically the applicable rule, its elements and, if the judgment denies plaintiff's claims, all rules that might support any of the claims. For each element of the rule, insofar as necessary, the justification clarifies the legal definition of the element as it relates to the particular case. Here the justification may interpret the applicable statute, but only to the extent directly relevant to determining whether the facts in the present case fulfill the elements of the statutory norm. Abstract discussions of law have no place.

The justification then tells the factual story of the case. It focuses on those facts material to decision of the case. Immaterial facts have no place in the justification except as is necessary to understand the court's decision. The justification starts from undisputed facts. Where facts are disputed, the justification evaluates the evidence that leads the court to decide as it does. The justification does not discuss burden of proof other than with respect to material facts in dispute.

Once the justification has clarified material and disputed facts, it subsumes those facts under the identified and clarified rule.

The judgment certifies that the procedure has fulfilled constitutional guarantees. These guarantees include that every exercise of state power has been justified by and grounded in statute, that the parties were heard, and that the parties received equal treatment under law. The judgment is an act of an impartial and impersonal public authority furnishing the 
official and objective interpretation and application of law. ${ }^{14}$ It helps parties understand why the court decided as it did. Ideally it convinces losing parties that the outcome is legally correct; at a minimum, it demonstrates that the process was rational.

\section{THE GERMAN JUDGMENT AS "NARRATIVE"}

Recent American writing on civil procedure conceptualizes contemporary American trials as a form of narrative, or more accurately, as a form of presentation of "two competing narratives... where an 'either-or' choice will have to be made." The narrative is how we "actually organize and analyze the vast amounts of information involved in making a legal judgment." 15 In this terminology, the German judgment is the narrative of German civil proceedings.

The difference between German and American proceedings narrative-wise is that the German judgment presents "the standard narrative historiography, where there exists a single account of events ...," while contemporary American proceedings present two fully formed and competing narratives at trial that have been developed pretrial. No wonder, then, that German civil procedure is more efficient than is its American counterpart; where American proceedings write two screenplays and produce both screenplays jointly in one trial, German civil procedure records only one report for posterity and does not even bother to dramatize it. While the German cinema is poorer for the paucity of scripts, the German legal system is richer in determinations of right.

The efficiency of German civil procedure does not end in it making one unproduced screenplay do where American procedures create and produce two. The monopoly position of the German narrative avoids the excesses of competing narratives. The German narrative focuses on that which is legally material. It does not battle for the reader's imagination. It does not bring into its story legally immaterial, but humanly appealing, detail. It does not leave out legally material matters that do not contribute to its justification. It is concerned with the validity of its conclusions. It has no cause to seek deconstruction of a competing version of events on grounds unrelated to the validity of those conclusions.

14. See Reinhard Zimmermann, Characteristic Aspects of German Legal Culture, in 1 InTRODUCTION to German LAw, 26-27 (Mathias Reimann \& Joachim Zekoll eds., 2005).

15. Robert P. Burns, The Distinctiveness of the Trial Narrative, in 1 THE TRIAL ON TRIAL: TRUTH AND DuE PRocess 157 (Anthony Duff et al., eds., 2004). 
The writer of the narrative in German civil procedure is the judge. The judge is assigned the task to write the story of whether the plaintiff has established facts that fulfill all of the elements of a statutory right. The parties provide the judge with the materials the judge needs for that work. The goal of their cooperation is a decision according to law. The individual elements required by statute to establish a claim are the "spectacles" through which the judge views the case. What the judge can see through the spectacles matters; everything else is immaterial. ${ }^{16}$

The "sporting theory of justice" is no model for German court proceedings; there is no trial by battle between competing champions. There is little theater, ceremony is sparing, courtrooms are modest and judges preside from an altitude of a few inches rather than from a height of a couple of feet. Parties and their attorneys talk directly with the judge and with each other. The atmosphere is more cooperative and less confrontational than that of their American counterparts. German court proceedings resemble joint projects such as assembling a jigsaw puzzle, completing a crossword puzzle or conducting a scavenger hunt. The principal difference between these joint activities and German court proceedings is that in court one party wants to establish that one piece is necessarily missing!

\section{THE RELATIONSTECHNIK AS GUIDE TO APPLYING LAW TO FACTS}

The Relationstechnik bounds legal proceedings without straitjacketing them. It avoids the two extremes of American civil procedure: the single-issue focus of historic common law special pleading and the legally unfocused narrative of contemporary notice pleading. It brings about issue narrowing without cutting off the right to be heard. The "golden rule" of German civil justice is that there are no surprise decisions. ${ }^{17}$ We discuss here four of the ways in which the Relationstechnik sets boundaries to litigation and keeps civil justice aligned with social goals: (1) reviewing the complaint for plausibility before serving; (2) case structuring through issue framing; (3) focusing witness testimony; and (4) deferring issue deciding.

16. JOACHIM HRUSCHKa, Die KONSTITUTION DES ReChTSFalles: STUdien ZUM VERHÄLTNIS VON TATSACHENFESTSTELLUNG UND RECHTSANWENDUNG 23-24 (1965).

17. Helmut Rüßmann, Grundregeln der Relationstechnik (Jan. 14, 2005), http://ruessmann.jura.uni-sb.de/zpo2004/Vorlesung/relationstechnik. htm. 


\section{(1) Reviewing the Complaint for Plausibility before Serving}

The Relationstechnik together with the cost system ${ }^{18}$ help keep lawsuits that are unfounded in fact or law or that are procedurally defective from being served on, and thus from disturbing, potential defendants. The plaintiff begins a lawsuit by filing a complaint with the court. Before the court serves the complaint on the defendant, it assigns the case to a judge who makes a preliminary review of the complaint for procedural prerequisites and other patent deficiencies. Already at this stage the Relationstechnik anticipates the judgment that is to come. The plaintiff must plead a case that has a plausible chance of success. While the plaintiff need not plead the legal basis on which the complaint rests, the plaintiff must plead facts upon which relief could be granted. Moreover, the plaintiff must plead the proof that the plaintiff intends to rely upon to prove the factual assertions, i.e., the plaintiff must "substantiate" the complaint's factual allegations. A properly substantiated complaint includes all material documents in the plaintiff's possession, designates all material documents in the possession of others, and identifies the testimony on which the plaintiff plans to rely. It should state the facts so exactly that, based on the information provided, the court could determine that the claimed legal relief should be granted.

The judge's preliminary review of the complaint impels plaintiffs' counsel to ground complaints in existing law and in facts that counsel has a reasonable chance of proving. The expectation of preliminary review helps deter frivolous complaints. Yet that review should not deter many meritorious complaints, since plaintiffs do not plead at their peril.

Should the judge have concerns about whether the procedural prerequisites are met, or about whether the complaint sufficiently substantiates the factual allegations, the judge is to direct the plaintiff to clarify the point before dismissing the case. ${ }^{19}$ Moreover, while it is the plaintiff's responsibility to plead the facts, it is up to the judge to know the law and to identify the applicable legal rule. In Germany, as in other civil law countries, the maxims jura novit curia (the court knows the law) and da mihi factum, dabo tibi ius (give me the facts, I will give you the law) apply. So long as there is any legal rule that would support relief on the facts alleged, the judge is to direct service of the complaint. The plaintiff's incorrect choice of rule is of no moment.

18. In Germany, the loser pays. Zivilprozessordnung [ZPO][Civil Procedure Statute] Jan. 30, 1877, \$ 91, ๆ1.

19. See Michael Bohlander, The German Advantage Revisited: An Inside View of German Civil Procedure in the Nineties, 13 TUL. EUR. \& CIV. L.F. 25, 33 (1998); MURRAY \& STÜRNER, supra note 8 , at 210. 
Once the judge directs service and the defendant is served, the defendant is required to answer the complaint. The defendant's answer is subject to requirements similar to those governing the complaint: it must be true, complete, specific, and substantiated.

\section{(2) Case Structuring through Issue Framing}

Coincident with the preliminary review, the judge determines how the case is to proceed further, whether the case will use additional written proceedings or will use a so-called early first hearing. The judge's choice is purely pragmatic; the judge selects the method that the judge thinks is most likely to be more efficient in the case. A party dissatisfied with the choice may request that the judge use the other method, in which case the party should state why the party believes that the other method would be more efficient. The determinant of efficiency is ordinarily which method is more likely to simplify and hasten framing of the material and disputed issues. The judges with whom I have spoken have told me that most judges prefer an early oral hearing in contested cases.

Prior to the first hearing, or the exchange of further written pleadings, as the case may be, the judge is required to prepare for the future proceedings. Preparations may include: (1) directing the parties to supplement their pleadings, (2) directing government authorities to provide information and documents, (3) ordering the personal appearance of the parties, (4) summoning witnesses named by a party to the hearing, and (5) ordering the production of documents or tangible things and making premises available for observation. In some cases, based on these preparations, it is possible to resolve the entire case at the first hearing.

In this stage the judge structures the lawsuit without finally deciding anything. The judge works with the parties to identify those issues that both are material to plaintiff's claims and that are in dispute. This early structuring of the case through issue framing plays an important role in keeping German civil justice within bounds. It identifies the legal rules under consideration for application, the elements of those rules, and the evidence necessary to establish the elements of each rule. The judge points out weaknesses to the parties in their particular claims and inquires of them how they plan to meet those claims.

Structuring the case and framing issues not only guides the judge in subsequent consideration of the case, it also helps the parties reach a settlement of the case more expeditiously and reasonably. The parties can see which rules will determine the decision and which facts are 
needed. Some judges told me that they consider structuring one of their most important judicial duties.

To an American accustomed to very formal exchanges between judge and counsel, the early first hearing to clarify issues is remarkable. By American standards, these hearings are intensely interactive, comparatively cooperative, and informal. ${ }^{20}$ They resemble American pretrial conferences more than American trials. They differ from American pretrial conferences, however, in important ways. Most remarkable from an American perspective is the role of the parties. Typically the judge summons the parties themselves to the early first hearing and speaks directly with them. These hearings are neither American-style discovery nor American-style trial. ${ }^{21}$ Their focus is on identifying material issues of fact that are actually in dispute between the parties; it is not on uncovering unknown facts, or on proving known ones, or on possible presentation of a narration later. ${ }^{22}$ The judge probes the potential claims and the facts needed to support the claims. In essence, the judge turns to the concerned party and the party's attorney and asks: "Now on this issue are you seriously going to dispute the fact?"

What prevents the party or the party's attorney from responding: so let the other side prove it? The German Code of Civil Procedure ("ZPO"). ZPO $\S 138$ imposes on parties a duty of cooperation in clarifying the issues in the case. ZPO $\S 138(1)$ requires the parties to give their declarations concerning factual circumstances completely and truthfully; ZPO $\S 138(2)$ requires that they state their positions with respect to the facts asserted by the opponent. These discussions are not evidentiary. They do not constitute taking testimony of the parties. They amount to clarification of the factual assertions of the parties that are necessary for the eventual application of the law to the facts. ZPO $\S 138(3)$ provides that an asserted fact will be treated as admitted if the other party is silent and fails to contest it. ZPO $\S 138(4)$ provides that only in limited circumstances does a declaration of lack of knowledge serve to put a matter in dispute. Moreover, ZPO $\S 138(2)$ is interpreted

20. Murray and Stürner describe them at some length. MURRAY \& STÜRNER, supra note 8 , at $256-59$.

21. See, e.g., Thomas D. Rowe, Jr., American Law Institute Study on Paths to a "Better Way": Litigation Alternatives, and Accommodation: Background Paper, 1989 DUKE L.J. 824, $854 \mathrm{n} .109$ (incorrectly so characterizing the hearing).

22. Cf. Frederick D. Wells, A Justice Factory, JUSTICE Through SIMPLIFIEd LEGAL Procedure, 73 AnNals AM. ACAD. POL. \& SOC. SCI. 196, 202 (1917):

The court could practically say: "Now on this issue are you seriously going to dispute the fact? As a reasonable man, are you denying it?" If he answers "Perhaps it is so, but, let the other side prove it," it ought to be possible for the court to throw his technical objections out of the window. 
to require that a mere denial of fact is not sufficient to put a fact in dispute. A party in most cases must explicitly contest the fact asserted, and if the fact asserted is known or could be known to the party, then the party must substantiate its contrary contention with facts known to it. Thus, if in the course of the hearing or in the pleadings, one party admits a fact asserted by the other, there is no need to prove the fact. In relatively short order the judge can inform the parties of the applicable legal rules and get their agreement on which matters of fact are material to those rules and are in dispute.

\section{(3) Focusing Witness Testimony}

Thanks to such structuring, many cases conclude without oral testimony of witnesses ever being necessary. Judges I spoke with estimated that this may be true of well more than half of all cases filed. Where witness testimony is taken, framing issues helps focus and expedite the testimony that is taken.

When it comes to taking the testimony of witnesses, German civil justice is just-in-time justice. The judge takes evidence only on party request and only after the judge so orders. ${ }^{23}$ The judge is to order taking evidence only when necessary to convince the judge of the truth or untruth of a particular fact that is disputed by the parties and that is material to the judge's decision of the case. Thus, the judge should not take evidence to prove undisputed facts, facts generally known to the judge, facts presumed by statute to be true until the contrary is proven, favorable facts established by the other party's submissions, disputed main facts established by undisputed facts, disputed facts the truth of which the judge is convinced of without taking evidence, and facts not necessary for the judgment (e.g., two alternatives for granting relief are allowed and one is already acknowledged).

The judge's control of evidence taking does not, however, prevent parties from insisting on taking evidence that they believe is relevant to deciding material issues in dispute. German judges told me that one of the surest ways to ensure that a lower court is reversed on appeal is to reject an application to take evidence without strong justification. Such refusal counts as a violation of the judge's ZPO $\S 139$ duty of elucidation discussed in the next subsection.

23. John Langbein has written eloquently of The German Advantage in Civil Procedure, 52 U. CHI. L. REV. 823 (1985). His main theme is that "by assigning judges rather than lawyers to investigate the facts, the Germans avoid the most troublesome aspects of our practice." Id. at 824 . His article led to a flurry of discussion that has continued over twenty years. A recent review can be found in Bradley Bryan, Justice and Advantage in Civil Procedure: Langbein's Conception of Comparative Law and Procedural Justice in Question, 11 TULSA J. COMP. \& INT'L L. 521 , 523 (2004). 


\section{(4) Deferring Final Decision of Issues}

Case structuring and issue framing work as powerful tools for promoting efficient conduct of civil justice because German judges can and do defer final decisions of individual aspects of cases until they are prepared to decide the case as a whole. German judges decide no issues before their time. $^{24}$ The critical moment in a German lawsuit is how law applies to facts as of the last oral hearing. German parties do not have to commit irrevocably early in the lawsuit to a single theory of the case. While judges are authorized to reject evidence for being offered too late, and often do that, their enthusiasm for such expediting measures is tempered by their ever-present ZPO $\S 139$ duty of elucidation which assures the parties their constitutional right to be heard guaranteed by the German Constitution. ${ }^{25}$ ZPO $\S 139$ is a far-reaching prescription that the judge thoroughly discuss all aspects of the case with the parties. It completely rules out trial by ambush. ZPO $\S 139(2)$ requires that the judge call to a party's attention and give the party an opportunity to comment on any non-trivial issue that the party has apparently overlooked or has considered insignificant or where the judge's understanding of the point of fact or law differs from the understanding of the parties.

German civil procedure seeks in this way to sequence issue deciding in a manner that is both efficient and just. In many cases, the applicable legal rule can not simply be read from the statute. Instead, it is often it necessary to search the statute for the rule, to compare the rule to the facts, to revisit the statute in light of the facts, and to examine the facts again in light of the rules. This process of going back and forth was identified in the first part of the twentieth century and has since assumed a place in the description of law application in Germany. ${ }^{26}$

\section{AMERICAN REFLECTIONS ON THE GERMAN RELATIONSTECHNIK}

The ideals that undergird the German Relationstechnik are no strangers to American civil justice. For much of the $20^{\text {th }}$ century the Canons of Judicial Ethics of the American Bar Association stated as a tenet of the rule of the law that the judge's "duty is the application of

24. Paul Masson advertising slogan "We will sell no wine before its time." See, e.g., Paul Masson Commercial Featuring Orson Welles, available at http:/www.youtube.com/ watch? $\mathrm{v}=$ bpj0t2ozPWY (last visited Sept. 19, 2009).

25. GRUNDGESETZ [GG] [Constitution] art.103 (F.R.G.).

26. See Oskar Hartwieg \& Hans Albrecht Hesse: Die Entscheidung IM ZIVILPROZESS: EIN STUDIENBUCH ÜBER METHODE, RECHTSGEFÜHL UND ROUTINE IN GuTACHTEN UND URTEIL 78-79 (1981) (Die Lehre vom Pendelblick). 
general law to particular instances., 27 The idea that civil procedure should guide deciding anchored our civil justice system throughout the $19^{\text {th }}$ century. Stephen on Pleading, the most often printed of all one volume treatises on civil procedure of that century, famously begins: "In the course of administering justice between litigating parties there are two successive objects, - to ascertain the subject for decision, and to decide." ${ }^{28}$ Proponents of narrative litigation acknowledge that even today the received view of the American trial describes an underlying substance $^{29}$ that seems to me scarcely different from the Relationstechnik: (1) construct an accurate, value-free account of what occurred, (2) fairly categorize whether that account fits within the substantive law, and (3) deliver a verdict that the party with the burden of proof has established each of the elements of the claim.

American civil procedure has, however, never enjoyed the success of the German Relationstechnik. It has swung from one extreme to the other-from allowing parties to dispute only one point of law or fact, as was the case in common law special pleading, to allowing parties to put forth all manner of claims constrained only slightly by statutory law. To keep the trial in bounds and to prevent unfair surprise, special pleading precluded parties from addressing all but one issue. To remedy the ills that followed from premature issue narrowing, the system introduced contemporary discovery to assure that parties did not narrow issues with incomplete knowledge. But the cure was worse than the ill; few cases can support complete discovery.

The inability of American civil procedure to narrow issues without cutting off consideration of matters later found to be material has rendered American civil procedure a failure. Contemporary American

27. Canons of Judicial Ethics, Canon 20 (1924). From 1924 to 1972 the American Bar Association's Canon 20 provided:

A judge should be mindful that his duty is the application of general law to particular instances, that ours is a government of law and not of men, and that he violates his duty as a minister of justice under such a system if he seeks to do what he may personally consider substantial justice in a particular case and disregards general law as he knows it to be binding on him.

Id. These canons remained in force until the Code of Judicial Conduct was adopted August 16, 1972. Model Code of Judicial CONduct Preface (1990).

28. Henry John Stephen, A Treatise on the Principles of Pleading in Civil ACTIONS 1 (Philadelphia, Abraham Small, 1824). The first American edition appeared in the year of the first edition in London, 1824. Before the Civil War, there were six subsequent editions by Francis J. Troubat. After the Civil War there were many more editions by different editors, among them one by that icon of the common law, Samuel Williston in 1895. Other editions included those by Franklin Fiske Heard (1867), Samuel Tyler (multiple editions from 1871 to 1919), and James DeWitt Andrews (multiple editions 1894-1901). It was epitomized in other books. It was the 19th century American guide to common law pleading. The last American edition appeared in 1924.

29. Burns, supra note 15. 
civil justice cannot do efficiently and justly that which the public rightly expects of it: apply law to facts to determine rights.

Common law special pleading and contemporary discovery have one thing in common: both rely on the good will of the parties' attorneys to narrow the issues. Problematic in any system, such an approach is especially dubious in an adversary system, particularly in an adversary system such as has developed in the United States, where the bar is diverse and open rather than limited and closed as it had been in England.

When the nineteenth century reformers contemplated abolition of common law pleading, some also contemplated shifting responsibility for issue narrowing from the parties to a neutral magistrate as in classical Roman law. Aware of the possibility, but apparently not familiar with a working system of such narrowing, they hesitated to import a "foreign style of architecture." Instead, they chose to try first to "build with old materials and after the old fashions." 30 They tried. April 12, 2008, was the $160^{\text {th }}$ anniversary of New York legislature's adoption of the Field Code. It is still the symbolic cornerstone of the rickety system we have today. Six generations of failure are enough; it is time for change. Knowledge of German Relationstechnik should inform that change. ${ }^{31}$

30. See, e.g., REPORT OF THE COMMISSIONERS APPOINTED TO REVISE AND REFORM THE PROCEEDINGS IN THE COURT OF JUSTICE IN THIS COMMONWEALTH (1851), reprinted in 2 a Memoir of Benjamin Robbins Curtis with Some of His Professional and Miscellaneous WRITING 159 (Benjamin R. Curtis, Jr. ed., 1879).

31. The acceptance of special pleading in $19^{\text {th }}$ century America dispels the idea that present-day story-writing procedures are mandated by the constitutional requirement of trial by jury. All that the Constitution requires is a jury trial of disputed issues of material fact. For the place of the Relationstechnik in German civil procedure generally, see James R. Maxeiner, Gyooho Lee \& armin Weber, Practical Global Civil Procedure: United States, Germany \& Korea (forthcoming 2010). 
